\section{Financial products as alternatives to traditional deposits}

Cristina Lidia MANEA, Bucharest University of Economic Studies, E-mail: lidia.manea@cig.ase.ro

\section{Anstract}

Economic and financial environment characterized by risks and uncertainties greatly influences the decision depositors as consumers of banking products. Often, the disadvantages of traditional deposits are the reasons that lead depositors to look for dangerous financial products that can provide the preservation of the purchasing power of the currency, the currency hedging, but assuming unknown additional risks due to the lack of information.

In this context, increasing the safety of depositors appears as an undisputed necessity, which translates to our approach in the development of a constructive applied research that takes into account the following stages: short description of risks and uncertainties characterizing the economic environment with emphasis on the importance of the financial instruments; analysis of empirical data on deposits in lei and euro at national level, identifying possible causes which led to one preference or another and finding the causes underlying the different options manifested in the capital, as compared to other counties; identifying the products that offer a dangerous alternative to traditional deposits from the Romanian banking market and describing these products and their related risks; the proposal of a new product, demonstrating its effectiveness by testing and confirmation of two hypotheses.

Keywords: Dangerous financial products, deposits, foreign currency risk, preserve purchasing power, risks and uncertainty

JEL Classification: G21, G23, M41

To cite this article:

Manea, C.L. (2016), Financial products as alternatives to

traditional deposits, Audit Financiar, vol. XIV, no. 5(137)/2016,

pp. 526-539, DOI: 10.20869/AUDITF/2016/137/526

Permanent link to this document:

http://dx.doi.org/10.20869/AUDITF/2016/137/526 


\section{Introduction}

Regardless of the attitude towards risk, depositors are looking for effective means to ensure the maintenance of the actual level of the deposit. This is becoming more difficult, especially because of inflation, interest rates and exchange rate. Furthermore, the link between currency risk and inflation creates multiple pressures.

The relationship between the exchange rate and the inflation rate has led to several theories. In 1921, Cassel (cited by Popescu, 2011) supported the theory of purchasing power parity (PPP). Alternatives to this theory were the models developed by Harrod (1933), Balassa (1964) and Samuelson (1964) (cited by Popescu, 2011) regarding the shape deviations from PPP. The models explain why the price is higher for developed countries than in developing countries. In Romania, the exchange rate fluctuation was seen as a deviation from the absolute version of PPP, and the change in the leu/dollar rate was often indicated as the cause of rising prices. Using the Granger causality concept, Pecican (2003) established the direction of the relationship between the exchange rate and the inflation rate: in Romania, the exchange rate has determined the price index change during the period.

When the pressures of inflation and exchange rate fluctuations are significant, it is necessary to preserve the purchasing power over a long time. But the traditional saving options, represented by deposits in lei or other currencies are exposed precisely to risks such as:

- Changes in currency exchange rates, and

- Exposure to inflation.

In recent years, the interest rate fails to cover entirely the negative impact of inflation rate, which influences the purchasing power of the national currency, causing the loss of currency value. If the effect of inflation rate is sometimes offset by the interest rates, in the case of exchange rate, the concern is amplified, due to the double influence which it exercises directly on deposits in different currencies and indirectly, through inflation rate on deposits in national currency made by businesses and households as consumers.

To overcome these inconveniences, depositors are choosing sophisticated financial products without knowing their related risks.

\section{The importance of knowing and understanding financial instruments as part of the financial education}

In an environment where the speed of response to market changes increases, instruments on the markets are continuously diversifying, and decisions are made in split seconds and are based on future events. We are surrounded by risks and uncertainties, because "life constantly recreates risks and uncertainties" (Giariani and Stahel, 1996, p 85). With the diversification of risks, the decision of depositors as consumers of financial products, acquires multiple meanings. Therefore, our attention should initially focus on the two concepts that influence the decision environment. But is the risk a problem or an opportunity?

If the general trend in the use of term risk emphasizes potential harm associated with it, in financial terms, the risk is seen as a deviation of the results of an event or activity from those expected, implying both the possibility of achieving superior results and the possibility of obtaining negative values. The risk can go in two directions: the result may be better or less good than expected, causing two trends known as "upside risk" and "downside risk" (Raftery, 1994). In these circumstances, the risk corresponds to the situation where there are several possible outcomes.

Unlike risk, the uncertainty is the situation where the decision outcomes are uncertain. "Uncertainty can be described as the sum of all the potential dangers around us, perceived or not" (Giariani and Stahel, 1996, p. 318).

The common element of the two concepts is that both risk and uncertainty correspond to decisions whose results have several possible alternatives. There is still one major difference between the two terms. According to Knight (1921, p. 233), the distinction between risk and uncertainty is that for risk "the distribution of the outcome in a group of instances is known", while in case of uncertainty probabilistic terms can not capture the randomness of events. Thus, the risk has a cyclic life (Arnesen, 1997), and the uncertainty is about situations that are unique. 
Risks and uncertainties have generated controversies over time. Keynes (1921) proposed the distinction between cardinal and ordinal probabilities. Skidelsky (2009) claimed that, along with these probabilities, Keynes put also the unknown probabilities. The reply not hesitate to show, so that a year later, Brady (2010) condemned this statement hard, considering that it was taken and supported in a wrong manner by all "postKeynes fundamentalists".

In the context of decision-making under risk, it has been introduced the idea of decreasing marginal utility. Bernoulli (1738) (cited by Schoemaker, 1982) argued that the utility people attach to a gain does not depend linearly on the gain, but increases by a rate that is reducing. The risk and uncertainty theories continued to develop and tried to explain the influence of these concepts on decisions of investors:

- The expected utility theory with objective probabilities (von Neumann şi Morgenstern, 1944, cited by Economics New School , 2007);

- The state-preference approach (Arrow, 1953; Debreu, 1959, cited by Economics New School, 2007);

- The expected utility theory with subjective probabilities (Savage, 1954, cited by Economics New School, 2007), introduced by Ramsey (1926), which argued that the probability of an event or activity depends on the personal opinions of the individual, thus giving the subjective nature. Indeed, there are market participants who have access to the same information and are making contradictory decisions being guided by the personal processing of that information. Bhatt (1987) observed that there is a double counting of the same risk, as determined by the different perceptions or expectations of the parties.

Mixing the two concepts introduced and expressed by Knight (1921) and Ramsey (1931), Holton (2004) stated that the risk corresponds to situations where the objective probabilities are calculated, while uncertainty is determined by subjective probabilities. History has shown us three attitudes towards risk that influence the consumers' decisions:

- Risk aversion, which has been carefully analyzed by Friedman and Savage (1948), who defined it as choosing the less risky alternative when earnings are close;
- Risk preference, and

- Indifference to risk.

Moreover, the attitude towards the risk may change depending on a number of subjective and/or objective factors.

To avoid risks or simply to assume more risks for higher outcome, all transactions entered today are based on financial instruments. Whether it is cash, receivables, debt instruments, bonds, deposits or derivatives, these instruments are used more often.

Financial instruments have developed over time with an amazing speed and the environment has been favorable for that: from the first banks that were the temples where the tithe was collected (Oppert, 1897, cited by Bromberg, 1942) to capital markets that have emerged and evolved as a result of financial innovations (Bhatt, 1987). The role of financial innovation was very important: Veblen (1904, cited by Hake, 1998) emphasized that the adoption of innovative financial instruments contributed to the rapid reorganization of American industry.

As a result of the explosion of financial innovation, new products were developed and refined: from currency futures to derivatives based on weather. The spectacular development characterized by continuous diversification of derivatives was a factor that acted negatively on understanding the mechanism of these products and knowledge of related risks, generating repeated controversy, which we described based on the dialecticconflict model. Many authors felt that financial instruments have been the cause of the financial crisis (Daschneider, 2009; Jubak, 2010; Summers, 2010; MacKenzie 2011). Moreover, Drâmba (2002) presented the financial speculations, stating that they are taking interesting shapes, unexpected, in a way comparable to betting or gambling. Stiglitz (2009) highlighted the dark side of the derivatives, arguing that they are instruments for gambling that do not provide transparency, creating difficulties to see and realize what is really happening. A few are those who identified other causes of financial crises, exempting the financial instruments: Jehle (1984) - lack of careful scrutiny of financial markets; Greenberger (2010) - unregulated markets.

Designed as tools to improve financial markets, derivatives proved to be sometimes tools of destruction of the financial system due to their incorrect use. Despite all that has happened, the companies continued to use 
them. A study conducted by the Association of Financial Professionals (1999) showed that $63 \%$ of respondents were using over the counter derivatives. The financial innovation was not the root of evil, nor the derivatives themselves are to blame, but the lack of regulations related to those who traded these instruments, especially the lack of full knowledge and understanding of these products. Mostly, the consumers were exposed to risks due to poor information on financial products. Moreover, even the initiators had limited knowledge on these complex products which made the hedging instruments to turn into more and unmanageable risktaking products.

History has shown where the lack of knowledge can lead regarding financial instruments: profits can be high, but losses can be much higher.

\section{Research methodology}

In our research we used several methods in order to increase the effectiveness of the results. To capture the option of businesses and households regarding the traditional deposits in domestic and foreign currency, we conducted an empirical analysis of data on these deposits, using as a search and data collection technique - the official statistics and archives of the National Bank of Romania (Ro. Banca Națională a României-BNO. As methods of treatment and analysis of data we used quantitative analysis by systematizing and calculation of indicators. The data refers to the deposits of non-bank and non-government customers from 2009 to 2015. The analysis covered both businesses and households as consumers of banking products. The data processed were nationwide, but focused on each county.

Then we searched for different types of deposit banking products from the Romanian market. The research was conducted based on the list of banks from the BNR website ( 37 banks) and consisted in classifying the deposits into five categories: lei deposits, euro deposits, structured deposits, unit links deposits, and gold accumulation plans.

Contributing to the increase of consumers' safety and to the diversification of risk management techniques, we conducted a constructive-type applied research, which aimed proposing and testing a financial instrument designed to protect against exchange rate variation. This banking product consists of a special term deposit - an amount in national currency and an amount in foreign currency in equal proportions at the date of origine, using the BNR exchange rate. The foreign currency is chosen by the depositor depending on his preference regarding the hedge of a certain exchange rate. More often, the currency pair is lei - euros.

We believe and we propose to demonstrate that this banking product offers an effective hedge against the exchange rate fluctuation by converting both of the currencies at maturity. Furthermore, this type of deposit can be used as a tool that results in a gain. The hypotheses that will be tested by logical-mathematical demonstrations are mentioned below.

Hypothesis $\mathbf{H 1}$ The lei - euro structured deposit leads to preserving purchasing power relative to the variation of the exchange rate, because the impairment recorded by one component of the deposit equals the increase in value recorded by the other component. In addition, the depositor will certainly gain the interest paid on deposit.

Hypothesis H2 The structured deposit in national and foreign currencies in equal proportions can be used as a tool to achieve a gain due to the increased purchasing power in relation to a foreign currency, plus the interest on the deposit.

\section{Results and discussions}

\subsection{Identifying the consumers' option for lei or foreign currency deposits}

After processing and analyzing the data, we concluded that, in the first part of the analysed period, the businesses and households from Bucharest have chosen the foreign currency deposits. Towards the end of period, the foreign currency deposits were easily exceeded by the lei deposits. The frequent changes of options depended on factors such as the increasing or the stagnating of exchange rate, the growth of inflation rate, and sensitive reduction of interest rates on deposits followed by a slight increase. The situation on the overall analysed period revealed the preference of businesses for lei and the preference of householders for foreign currency.

The national ${ }^{1}$ analysis revealed that both businesses and households have chosen national currency deposits to the detriment of the foreign currency deposits.

${ }^{1}$ Considering 41 counties 
The analysis on each county in Romania, except Bucharest and llfov, revealed a constant interest shown by businesses to save their money in the national currency during 2009-2015. The households are maintaining their option for deposits in lei, with one exception: in Timiş County the foreign currency deposits are greater than the domestic currency deposits.

The striking option difference between the capital and other counties (except Timiş) could be based on one or more of the following causes:

- Poor information of the depositors from the province, especially from rural areas;

- Poor financial education of households and businesses;

- Perception of a high currency risk due to the volatility of exchange rates, or conversely, feeling an appreciation of the national currency, which fosters the option to foreign currency loans and deposits in lei;
- Predominance of the risk averse depositors;

- Seeing a gain due to the interest on deposits in lei that is higher than that of the deposits in foreign currencies, without taking into account the inflation rate;

- Lack of foreign investors.

The major disadvantage of traditional deposits in lei is the loss of purchasing power of money, while the major disadvantage of traditional deposits in foreign currency is the decreasing of exchange rates.

\subsection{Deposits banking products from Romanian market - dangerous alternatives to traditional deposits}

From the total of 37 banks, 30 banks were eligible (some of them being the subject of fusion operations). The research points out that the banks deposits offer is based on the traditional types of deposits in lei and euro (as shown in Table 1).

\section{Table 1. Types of deposits}

\begin{tabular}{|c|c|c|c|c|c|c|}
\hline No. & Bank & $\begin{array}{c}\text { Lei } \\
\text { deposits }\end{array}$ & $\begin{array}{l}\text { Euro } \\
\text { deposits }\end{array}$ & $\begin{array}{l}\text { Structured } \\
\text { deposits }\end{array}$ & $\begin{array}{l}\text { Unit links } \\
\text { deposits }\end{array}$ & $\begin{array}{c}\text { Gold accumulation } \\
\text { plans }\end{array}$ \\
\hline 1. & Alpha Bank & $\mathrm{x}$ & $\mathrm{x}$ & & & \\
\hline 2. & $\begin{array}{l}\text { Banca C.R. Firenze Intesa } \\
\text { Sanpaolo Bank }\end{array}$ & $x$ & $x$ & & & \\
\hline 3. & Banca Comerciala Carpatica & $\mathrm{x}$ & $\mathrm{x}$ & & $\mathrm{x}$ & \\
\hline 4. & $\begin{array}{l}\text { Banca Italo Romena - Veneto } \\
\text { Banca }\end{array}$ & $\mathrm{x}$ & $\mathrm{x}$ & & & \\
\hline 5. & Banca Romaneasca & $x$ & $x$ & & & \\
\hline 6. & Banca Transilvania & $\mathrm{x}$ & $\mathrm{x}$ & & $\mathrm{x}$ & \\
\hline 7. & BANCPOST & & & $x$ & $x$ & \\
\hline 8. & Banca Comercială Romana & $\mathrm{x}$ & $\mathrm{x}$ & $\mathrm{x}$ & $\mathrm{x}$ & \\
\hline 9. & $\mathrm{BRD}$ & $\mathrm{x}$ & $\mathrm{x}$ & & $\mathrm{x}$ & \\
\hline 10. & CEC & $\mathrm{x}$ & $\mathrm{x}$ & & & \\
\hline 11. & Citi Bank & $\mathrm{x}$ & $\mathrm{x}$ & $\mathrm{x}$ & $\mathrm{x}$ & \\
\hline 12. & Credit Europe Bank & $\mathrm{x}$ & $\mathrm{x}$ & & & \\
\hline 13. & $\begin{array}{l}\text { Egnatia Bank (Romania) SA - } \\
\text { Marfin Bank (Romania) SA }\end{array}$ & $\mathrm{x}$ & $\mathrm{x}$ & & & \\
\hline 14. & $\begin{array}{l}\text { Emporiki Bank - Romania - } \\
\text { Credit Agricole }\end{array}$ & $\mathrm{x}$ & $\mathrm{x}$ & & & \\
\hline 15. & Garanti Bank & $\mathrm{x}$ & $x$ & & & \\
\hline 16. & ING Bank N.V. & $\mathrm{x}$ & $\mathrm{x}$ & $\mathrm{x}$ & $\mathrm{x}$ & \\
\hline
\end{tabular}




\begin{tabular}{|r|l|c|c|c|c|c|}
\hline No. & \multicolumn{1}{|c|}{ Bank } & $\begin{array}{c}\text { Lei } \\
\text { deposits }\end{array}$ & $\begin{array}{c}\text { Euro } \\
\text { deposits }\end{array}$ & $\begin{array}{c}\text { Structured } \\
\text { deposits }\end{array}$ & $\begin{array}{c}\text { Unit links } \\
\text { deposits }\end{array}$ & $\begin{array}{c}\text { Gold accumulation } \\
\text { plans }\end{array}$ \\
\hline 17. & La Caixa + BCR & $\mathrm{x}$ & $\mathrm{x}$ & & & \\
\hline 18. & Leumi Bank Romania & $\mathrm{x}$ & $\mathrm{x}$ & & & \\
\hline 19. & Libra Bank & $\mathrm{x}$ & $\mathrm{x}$ & & & \\
\hline 20. & Millennium Bank & $\mathrm{x}$ & $\mathrm{x}$ & $\mathrm{x}$ & & \\
\hline 21. & OTP Bank Romania S.A. & $\mathrm{x}$ & $\mathrm{x}$ & $\mathrm{x}$ & & \\
\hline 22. & OTP Bank Romania S.A. & $\mathrm{x}$ & $\mathrm{x}$ & & & \\
\hline 23. & Piraeus Bank Romania & $\mathrm{x}$ & $\mathrm{x}$ & & & $\mathrm{x}$ \\
\hline 24. & ProCredit Bank & $\mathrm{x}$ & $\mathrm{x}$ & & & \\
\hline 25. & Raiffeisen Bank & $\mathrm{x}$ & $\mathrm{x}$ & & $\mathrm{x}$ & \\
\hline 26. & RBS & $\mathrm{x}$ & $\mathrm{x}$ & $\mathrm{x}$ & & \\
\hline 27. & Romanian International Bank & $\mathrm{x}$ & $\mathrm{x}$ & & & \\
\hline 28. & Sanpaolo Imi Bank Romania & $\mathrm{x}$ & $\mathrm{x}$ & & & \\
\hline 29. & UniCredit Țiriac Bank & $\mathrm{x}$ & $\mathrm{x}$ & $\mathrm{x}$ & $\mathrm{x}$ & \\
\hline 30. & Volksbank Romania & $\mathrm{x}$ & $\mathrm{x}$ & & & \\
\hline
\end{tabular}

Source: Author's processing

As an alternative to traditional deposits in domestic and foreign currency, banks promoted structures deposits

and unit link deposits, while the conversion in gold is less represented as illustrated in Figure 1.

\section{Figure 1. Standard and alternative deposits}

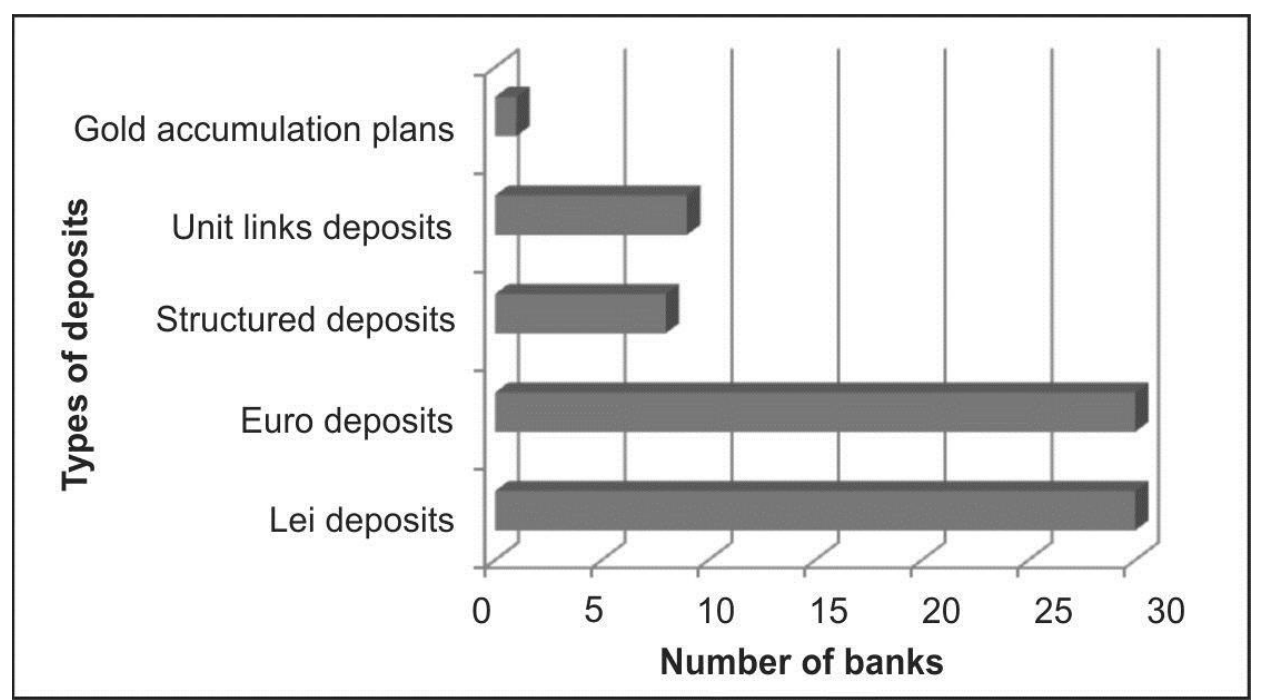

Source: Author's processing

Structured products are dependent on exchange rate variation and are known as dual currency deposits. Such deposits are financial instruments created by combining a term deposit with a derivative, which implies that at 
maturity the depositor will collect the initial amount and the interest in another currency than the deposit principal currency.

The conversion is done using an exchange rate mutually agreed by both parties to the initiation of the deposit, known as conversion rate. This is the BNR exchange rate plus a margin that varies depending on the bank. Usually, if the exchange rate announced by the BNR (reference rate at maturity of the deposit) is less than/equal to the conversion rate, then the deposit will be liquidated in the initial currency (e.g. euro). Conversely, if the exchange rate announced by the BNR is greater than the exchange rate, then the deposit will be liquidated in an alternative currency (lei).

The dual currency deposit is different from a classic term deposit by the following aspects:

- Assuming the risk that at the maturity the deposit amount to be converted in the alternative currency using a predetermined exchange rate (conversion rate) (Banc Post, 2016);

- To compensate for the risks assumed, the returns are usually higher than those for standard deposits (Piraeus Bank, 2016).

Such foreign exchange structured deposits are charged with a certain risk and contain elements of uncertainty

(Citi Bank, 2016). The main risks related to the dual currency deposits include, but are not limited to:

- The risk of exchange rate fluctuations: the performance of the deposit will depend largely on the exchange rate, which is influenced by national and international economic and political factors, by speculative actions of investors;

- The risk of early liquidation of the deposit: the assumption of reduced earnings if the deposit is liquidated before maturity.

In these circumstances, depending on the foreign exchange evolution, the depositor may either:

- Achieve returns higher than those from a standard term deposit;

- Obtain no gain (lack of gain);

- Recording a loss.

Other banking products that offer an improved yield of investments are barrier deposits and bonus deposits (BRD, 2016).

All these deposits are leading to a higher net benefit to that achieved in a standard term deposit, but only if the scenario of the exchange rate fluctuation is confirmed. Depositors are given the possibility to make a profit, but are not guaranteed to achieve it. Moreover, they may incur losses and in these cases the consumers' safety is affected especially when they have limited knowledge about these products.

Based on the related risks, we can classify the deposits mentioned above as dangerous banking products useful to the risk lovers. We can limit the negative impact of these products in two ways:

- Through the financial education, and

- By promoting products with low related risks.

If the first solution is a long-term process, hampered by the understanding capacity of depositors and their territorial dispersion, the second solution is the optimal one. Why promote dangerous financial products instead of those that are safe? Those who exhibit risk aversion are looking for deposits that are not affected by exchange rate fluctuations.

Thus, we may say that there is a need to propose and promote products that provide the preservation of the purchasing power without any linked risks. After careful consideration of the banking products on the Romanian market, we concluded that no bank has promoted such a deposit. Therefore, the solution we propose is an original one.

\subsection{Discussions and conclusions regarding the proposed financial product}

To overcome the disadvantages of the traditional products and to avoid additional risk taking by choosing a dangerous financial product, we propose a deposit in domestic and foreign currencies in equal proportions. Below are tested the hypotheses set out in the research methodology section.

Testing hypothesis $\mathrm{H} 1$. Let $\lambda$ an amount in lei and $\theta$ the equivalent value in euro at the exchange rate from $t_{0}$, so:

$$
\lambda=\theta \cdot c v_{0}
$$

As an alternative to investment opportunities in lei or euros, we propose a deposit with two components:

- Half lei: Dlei \& $€(l e i) t_{0}=\frac{\lambda}{2} l e i$ and 
- Half euros: Dlei \& $€(€) t_{0}=\frac{\theta}{2} €$

The equivalent interest earned for the two components has been neglected in order to capture the gain or loss recorded due to the exchange rate fluctuation.

On maturity of the deposit, the exchange rate will be $\mathrm{cv}_{1}$, and the two deposits will have the same nominal value as at the initiation:

Dlei \& $€(l e i) t_{1}=\frac{\lambda}{2} l e i$ and

Dlei \& $€(€) t_{1}=\frac{\theta}{2} €$

By converting each component of the deposit to $t_{1}$ we have:

Dlei \& $€(l e i \rightarrow €) t_{1}=\frac{\lambda}{2} \cdot \frac{1}{c v_{1}}$ and
Dlei $\& €(€ \rightarrow l e i) t_{1}=\frac{\theta}{2} \cdot c v_{1}$

Where:

Dlei \& $€(l e i \rightarrow €) t_{1}$ is the lei component to $t_{1}$ with conversion in euros, and

Dlei \& $€(€ \rightarrow$ lei $) t_{1}$ is the euros component to $t_{1}$ with conversion in lei.

Then we have emphasized the situation for each component of the deposit and for the entire deposit at the time of conversion (Table 2). It is noted that regardless of exchange rate changes, the lei-euros deposit is not affected by the depreciation or appreciation of currencies, providing a $100 \%$ hedge against the exchange rate fluctuations.

Even if the currencies structure of the deposit changes, the total value of the deposit is not eroded over time, despite of the recording of increases or decreases in the exchange rate.

Table 2. Increase and/or loss of purchasing power recorded for each component of the deposit and for the entire deposit

\begin{tabular}{|c|c|}
\hline Lei - euros deposit & Increase or loss \\
\hline $\begin{array}{l}\text { Devaluation or appreciation of the component in } \\
\text { lei: } \Delta \text { Dlei\& } \epsilon(l \dot{\boldsymbol{k}} \rightarrow \epsilon)\left(t_{1}-t_{0}\right)=\frac{\lambda}{2} \cdot \frac{1}{c v_{1}}-\frac{\lambda}{2} \cdot \frac{1}{c v_{0}}=\frac{\lambda}{2}\left(\frac{1}{c v_{1}}-\frac{1}{c v_{0}}\right)=-\frac{\lambda \Delta c v^{2}}{2 c v_{0} c v_{1}}\end{array}$ & $\begin{array}{l}\text { Increase, if } \Delta c v<0 \\
\text { Loss, if } \Delta c v>0 \\
\text { Zero, if } \Delta c v=0\end{array}$ \\
\hline $\begin{array}{l}\text { Devaluation or appreciation of the component in euros: } \\
\Delta D l e i \& \epsilon(\epsilon \rightarrow l e i)\left(t_{1}-t_{0}\right)=\frac{\theta}{2} \cdot c v_{1}-\frac{\theta}{2} \cdot c v_{0}=\frac{\theta}{2} \Delta c v\end{array}$ & $\begin{array}{c}\text { Loss, if } \Delta c v<0 \\
\text { Increase, if } \Delta c v>0 \\
\text { Zero, if } \Delta c v=0\end{array}$ \\
\hline $\begin{array}{l}\text { Devaluation or appreciation of both components: } \\
\text { - denominated in euros: } \\
\Delta \text { Dlei\& } \epsilon(l i, \epsilon \rightarrow \epsilon)\left(t_{1}-t_{0}\right)= \\
=\Delta \text { Dlei \& } \epsilon(l i \rightarrow \epsilon)\left(t_{1}-t_{0}\right)+\Delta \text { Dlei \& } \epsilon(\epsilon \rightarrow \text { lei })\left(t_{1}-t_{0}\right) \cdot \frac{1}{c v_{1}}= \\
=-\frac{\lambda \Delta c v}{2 c v_{0} c v_{1}}+\frac{\theta \Delta c v}{2 c v_{1}}=-\frac{\lambda \Delta c v}{2 c v_{0} c v_{1}}+\frac{\lambda}{c v_{0}} \cdot \frac{\Delta c v}{2 c v_{1}}=0 \\
\text { or } \\
\text { - denominated in lei: } \\
\Delta \text { Dlei\& } \epsilon(l i, \epsilon \rightarrow l e i)\left(t_{1}-t_{0}\right)= \\
=\Delta D l e i \& \epsilon(l i \rightarrow \epsilon)\left(t_{1}-t_{0}\right) \cdot c v_{1}+\Delta D l e i \& \epsilon(\epsilon \rightarrow l e i)\left(t_{1}-t_{0}\right)= \\
=-\frac{\lambda \Delta c v}{2 c v_{0} c v_{1}} \cdot c v_{1}+\frac{\theta \Delta c v}{2}=-\frac{\theta \cdot c v_{0} \Delta c v}{2 c v_{0}}+\frac{\theta \Delta c v}{2}=0\end{array}$ & $\begin{array}{c}\text { ZERO, } \\
\text { whether } \\
\Delta c v>0 \text { or } \Delta c v \leq 0\end{array}$ \\
\hline
\end{tabular}

Source: Author's processing

No. $5(137) / 2016$ 
To highlight the advantage of using such a deposit, we propose a comparative presentation for three scenarios: a lei deposit, a euro deposit and a lei\&euros deposit - in equal proportions, being the equivalent of the deposit in lei or euros (Table 3 ).
As expected, based on the exchange rate evolution for the deposits in lei and euros there are both the possibility of recording an increased purchasing power or a loss purchasing power.

\section{Table 3. Analysis of the exchange rate influence on deposits in lei, euros or lei - euros}

\begin{tabular}{|c|c|c|c|}
\hline & Lei deposit & Euros deposit & Lei - euros deposit \\
\hline$t_{0}$ & Dlex(lei)t $_{0}=\lambda$ & $D €(€)_{0}=\theta$ & $\begin{array}{l}\text { Dlei\& } €(l e i) t_{0}=\frac{\lambda}{2} \\
\text { Dlei\& } €(€)_{0}=\frac{\theta}{2}\end{array}$ \\
\hline \multirow{8}{*}{$t_{1}$} & $D^{2}\left(l(l e i) t_{1}=\lambda\right.$ & $D €(€)_{1}=\theta$ & $\begin{array}{l}\text { Dlei\& } €(l e i) t_{1}=\frac{\lambda}{2} \\
\text { Dlei\& } €(€)_{1}=\frac{\theta}{2}\end{array}$ \\
\hline & \multicolumn{3}{|c|}{ Increase or loss of purchasing power depending on exchange rate } \\
\hline & $\begin{array}{l}\Delta \text { Dlei\& } €(l e i \rightarrow €)\left(t_{1}-t_{0}\right)= \\
=\frac{\lambda}{c v_{1}}-\frac{\lambda}{c v_{0}}=-\frac{\lambda \Delta c v}{c v_{0} c v_{1}}\end{array}$ & $\begin{array}{l}\Delta \text { Dlei\& } €(€ \rightarrow l e i)\left(t_{1}-t_{0}\right)= \\
=\theta \cdot c v_{1}-\theta \cdot c v_{0}=\theta \cdot \Delta c v\end{array}$ & $\begin{array}{l}\Delta D l e i \& €(l e i \rightarrow €)\left(t_{1}-t_{0}\right)= \\
=-\frac{\lambda \Delta c v}{2 c v_{0} c v_{1}} \\
\Delta \text { Dlei\& } €(€ \rightarrow \text { lei })\left(t_{1}-t_{0}\right)= \\
=\frac{\theta}{2} \Delta c v \\
\Delta \text { Dlei\& } €(l e i, \epsilon)\left(t_{1}-t_{0}\right)=0\end{array}$ \\
\hline & $\begin{array}{c}\text { Increase, if } \Delta c v<0 \\
\text { Loss, if } \Delta c v>0 \\
\text { Zero, if } \Delta c v=0\end{array}$ & $\begin{array}{c}\text { Loss, if } \Delta c v<0 \\
\text { Increase, if } \Delta c v>0 \\
\text { Zero, if } \Delta c v=0\end{array}$ & $\begin{array}{c}\text { ZERO, } \\
\text { whether } \\
\Delta c v>0 \text { or } \Delta c v \leq 0\end{array}$ \\
\hline & & & $\begin{array}{l}\text { Unrecorded increase or loss as } \\
\text { against the lei deposit }\end{array}$ \\
\hline & & & $\begin{array}{l}\text { - as for lei component: } \\
=-\frac{\lambda \Delta c v}{2 c v_{0} c v_{1}}-\left(-\frac{\lambda \Delta c v}{c v_{0} c v_{1}}\right)=\frac{\lambda \Delta c v}{2 c v_{0} c v_{1}} \\
\text { - as for both components: } \\
=0-\left(-\frac{\lambda \Delta c v}{c v_{0} c v_{1}}\right)=\frac{\lambda \Delta c v}{c v_{0} c v_{1}}\end{array}$ \\
\hline & & & $\begin{array}{l}\text { Unrecorded increase or loss as } \\
\text { against the euros deposit }\end{array}$ \\
\hline & & & $\begin{array}{l}\text { - as for euros component: } \\
=\frac{\theta}{2} \Delta c v-\theta \cdot \Delta c v=-\frac{\theta}{2} \Delta c v \\
\text { - as for both components: } \\
=0-\theta \cdot \Delta c v=-\theta \cdot \Delta c v\end{array}$ \\
\hline
\end{tabular}

Source: Author's processing 
Unlike the traditional banking products of investment, the lei - euros deposit does not allow the depreciation or appreciation of initial values, being a banking product addressed to depositors with risk aversion to exchange rate variation (Table 4, Figure 2).

\section{Table 4. The influence of the exchange rate on the three types of deposits}

\begin{tabular}{|l|c|c|}
\hline \multirow{2}{*}{\multicolumn{1}{|c|}{ Types of deposits }} & \multicolumn{2}{|c|}{ Conversion results } \\
\cline { 2 - 3 } & \multicolumn{2}{|c|}{ when } \\
\hline Lei deposit & exchange rate increases & exchange rate decreases \\
\hline Euros deposit & $-\alpha$ & $+\beta$ \\
\hline Lei - euros deposit & $-\alpha$ & $-\beta$ \\
- as for lei component & $-\frac{1}{2} \alpha$ & $+\frac{1}{2} \beta$ \\
- as for euro component & $+\frac{1}{2} \alpha$ & $-\frac{1}{2} \beta$ \\
- as for both components & 0 & 0 \\
\hline
\end{tabular}

Source: Author's processing, 2016

\section{Figure 2. Gain or loss recorded on Lei - Euro deposit}

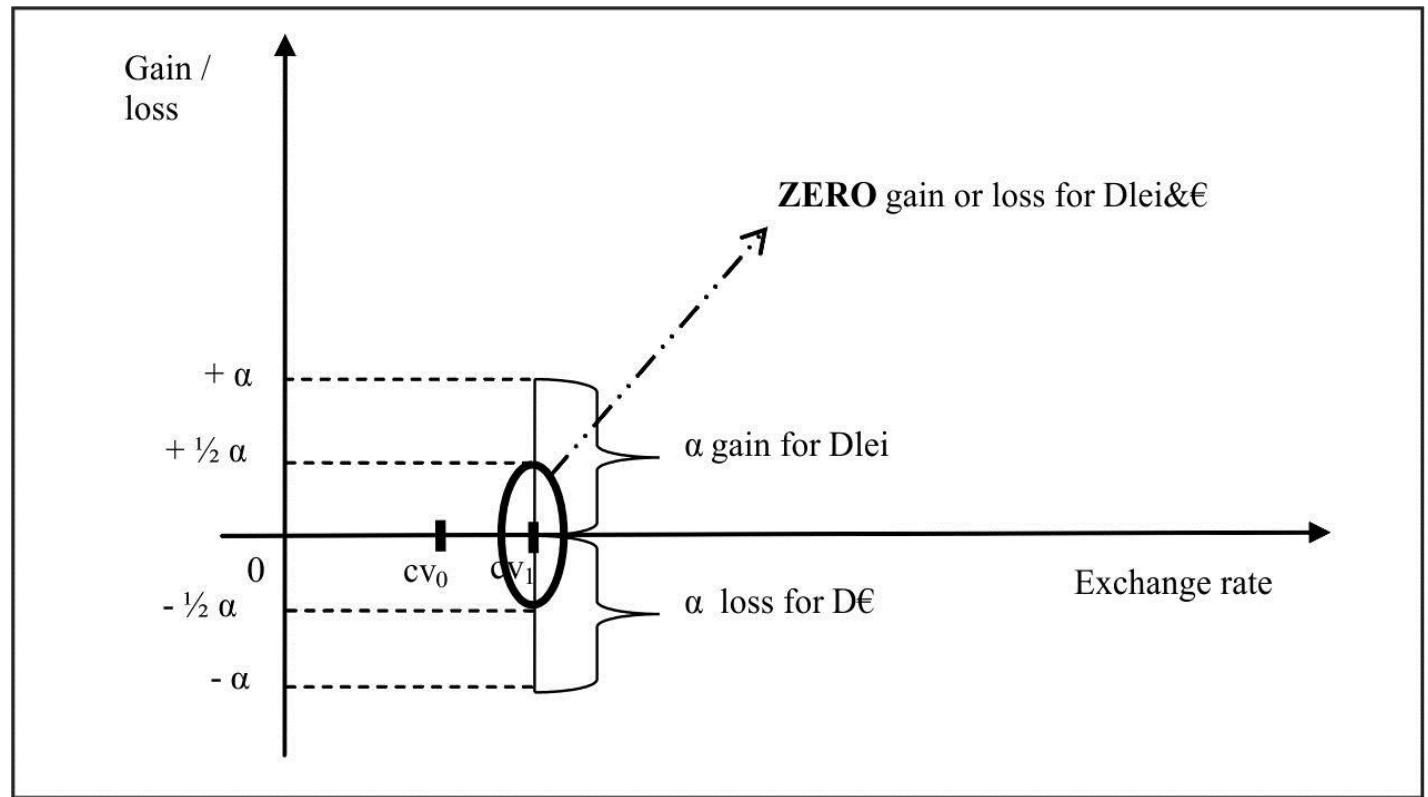

Source: Author's processing, 2016

We should emphasize that, in terms of accounting, domestic and foreign currency deposit results in the recognition of a foreign exchange loss or gain. The recognition of foreign exchange loss or gain for foreign 
component only, and not for the lei, generates an asymmetry that cannot result in zero accounting gain or loss. This can be considered a limit of the proposed model, but we will demonstrate that it can be partially removed.

From the accounting perspective, the expenses of foreign exchange represent a loss with a negative influence on cash in lei. In this case, there should be considered the cash at the end and the cash at the beginning of the period, without taking into account the conversion of the currency in lei.

It is not indicated to express either in lei nor in euros the total amount of the deposit, because it cancels the effect of exchange rate variation on one of the components.

Correlating the effect of avoiding currency risk with the interest received for each component of the lei - foreign currency deposit, we can say that the saving of money acquires new meanings: preserving the purchasing power of the amounts in relation to the exchange rate and the receipt of the deposit interest.

In addition, this type of deposit can be used not only as a tool to maintain the purchasing power in relation to foreign exchange rate, but as a speculation tool of the exchange rate variation.

Testing hypothesis $\mathbf{H} \mathbf{2}$. When the deposit is used as a means of gain, there should be converted only a part of the deposit - the component that has appreciated. Two scenarios should be considered in this regard.

Scenario 1. At maturity, the exchange rate decreased. The deposit holder will convert only the lei component of the deposit, using the BNR exchange rate at maturity, thus achieving an increase of $1 / 2 \beta$ in the purchasing power against euros.
For the euros component for which the conversion would generate a $1 / 2 \beta$ loss, the depositor may choose one of the following options:

- Using the amount in euros to make a new lei - euros deposit, or

- Using the amount in euros to pay existing debts in euros (or lei with settlement in euros) for which financial gains were recorded for the changing in fair value of debt that can offset partially or totally the loss; the effect would be similar to that of a hedging tool.

Scenario 2. At maturity, the exchange rate increased.

The deposit holder will convert none but the euros component of the deposit, using the BNR exchange rate at maturity, thus achieving an increase of $1 / 2 a$ in the purchasing power against national currency.

For the lei component for which the conversion would generate a $1 / 2$ a loss, the depositor may choose one of the following:

- Using the amount in lei to make a new lei - euros deposit, or

- Using the amount in lei to pay existing debts in lei so that the depreciation of the deposit to be offset by the depreciated liability.

Due to the possibility of partial conversion, the effect achieved at maturity of a national - foreign currency deposit in equal proportions can be:

- Avoiding the currency risk, or

- Increasing purchasing power for the component which has appreciated in value (Table 5).

\section{Table 5. The influence of the exchange rate on the lei - euros deposit}

\begin{tabular}{|c|c|c|c|c|}
\hline \multirow{3}{*}{ Lei-euros deposit } & \multicolumn{2}{|c|}{ Conversion results } & \multicolumn{2}{|c|}{ Partial conversion results } \\
\hline & \multicolumn{2}{|c|}{ when } & \multicolumn{2}{|c|}{ when } \\
\hline & $\begin{array}{c}\text { exchange rate } \\
\text { increases }\end{array}$ & $\begin{array}{c}\text { exchange rate } \\
\text { decreases }\end{array}$ & exchange rate increases & $\begin{array}{l}\text { exchange rate } \\
\text { decreases }\end{array}$ \\
\hline $\begin{array}{l}\text { - as for lei component } \\
\text { - as for euros component } \\
\text { - as for both components }\end{array}$ & $\begin{array}{c}-\frac{1}{2} \alpha \\
+\frac{1}{2} \alpha \\
0\end{array}$ & $\begin{array}{c}+\frac{1}{2} \beta \\
-\frac{1}{2} \beta \\
0\end{array}$ & $\begin{array}{l}\text { No conversion } \\
\begin{array}{l}+\frac{1}{2} \alpha \\
+\frac{1}{2} \alpha\end{array}\end{array}$ & $\begin{array}{c}+\frac{1}{2} \beta \\
\text { No conversion } \\
+\frac{1}{2} \beta\end{array}$ \\
\hline
\end{tabular}

Source: Author's processing 
Thus, this type of deposit is addressed to risk aversion depositors, allowing the preservation of the purchasing power by eliminating the influence of exchange rate or even the speculation or appreciation of one currency of the deposit, offering, in both cases, a guaranteed net gain as the interest received.

Promoting such a deposit in spite of dangerous financial products will lead to improved safety of consumers.

\section{Ponclusions}

The unstable economic and financial environment has negative effects on the purchasing power of the currency, the currency risk creating troubles in both businesses and households as consumers of banking products.

Depositors are looking to preserve the purchasing power over the long term. In these circumstances, the traditional deposits become outdated and depositors are choosing dangerous financial products.

While the risks seem to be the same, the financial products are diversifying continuously, with negative impact on the financial education of users of such tools.
Contributing to the increase of consumers' safety, we conducted a constructive-type applied research, which aimed proposing and testing a financial instrument designed to protect against the exchange rate variation. This instrument consists of a special deposit - national and foreign currency in equal proportions - which allows the preservation of the purchasing power by eliminating the negative influence of the exchange rate, being addressed to investors with risk aversion. Furthermore, the proposed instrument can be used in speculating the appreciation of one currency deposit. In both cases, the proposed instrument offers a guaranteed net gain as interest earned.

Replacing dangerous financial products with such a tool will result in increased consumer safety.

After comparing the products of the Romanian banking market, we concluded that this tool provides a clear advantage, due to the low related risks. The limit identified and partially resolved regarding the accounting information asymmetry among companies can be a starting point for a future research.

\section{REFERENCES}

1. Arnesen, T. (1997), Risk, Uncertainty and Communication: A Discussion, Society for Risk Analysis-Europe Annual Meeting, [online] Availalble at: http://www.riskworld. com/abstract/1997/Europe97/eu7ab008.htm [Accessed 25 October 2015].

2. Association for Financial Professionals, (1999), Survey of OTC Derivatives Use and Risk Management Practices, [online] Availalble at: $<$ http://archives.financialservices. house.gov/ banking/41100mi1.pdf> [Accessed 17 October 2015].

3. Banc Post, (2016), Depozit de tipul dual currency depozit în EUR, [online] Availalble at: <http://www. bancpost.ro/Handlers/MIDADynamicFile.ashx/99/D CD_eurron_site.pdf> [Accessed 02 March 2016].

4. Bhatt, V. (1987), Financial Innovations and Credit Market Evolution, Economic and Political Weekly, [e-journal] vol. 22, no. 22, pp. 823-M76, Availalble at: <http://www.jstor.org/stable /4377042> [Accessed 17 October 2015].
5. Brady, M.E. (2010), Skidelsky ignores the Boolean foundations of Keynes's theory of probability, [online] Availalble at: <http://www.amazon.com/ Keynes-Return-Master-Robert-Skidelsky /dp/0141043601> [Accessed 23 October 2015].

6. BRD (2016), Soluții pentru îmbunătățirea randamentului plasamentelor, [online] Availalble at: <http://www.brd.ro/\&files/depozite-structurate.pdf> [Accessed 02 March 2016].

7. Bromberg, B. (1942), The Origin of Banking: Religious Finance in Babylonia, The Journal of Economic History, [e-journal] vol. 2, no. 1, pp. 77-88, DOI: 10.107/S002205070005230X, Availalble at: http://www.jstor.org/stable/2113028 [Accessed 25 October 2015].

8. Citi Bank (2016), Depozite structurate de tipul dual currency, [online] Availalble at: <http://www. citibank.ro/citigold/docs/Document_de_prezentare_ depozite_structurate_dual_currency_V4.pdf> [Accessed 02 March 2016]. 
9. Daschneider (2009), Exotic financial instruments, you say?, When History Attacks!, [online] Availalble at: http://whenhistoryattacks.wordpress. com/2009/05/28/exotic-financial-instruments-yousay/, [Accessed 17 October 2015].

10. Drâmba, O. (2002), Istoria culturii şi civilizației, Bucureşti: Saeculum I.O, Vestala.

11. Economics New School (2007), Choice under Risk and Uncertainty, [online] Availalble at:

$<$ http://homepage.newschool.edu/ het/essays/unc ert/choicecont.htm> [Accessed 25 October 2015].

12. Giariani, O. and Stahel, R.W. (1996), Limitele certitudinii: înfruntând riscurile în noua economie a serviciilor, Bucureşti: Edim Press-Campo.

13. Greenberger, M. (2010), The Role of Derivatives in the Financial Crisis, Financial Crisis Inquiry Commission Hearing, [online] Availalble at: http://fcic-static.law.stanford. edu/cdn_media/fcictestimony/2010-0630-Greenberger.pdf [Accessed 17 October 2015].

14. Hake, E. (1998), Financial Innovation as Facilitator of Merger Activity, Journal of Economic Issues, [ejournal] vol. 32, no. 1, pp. 145-170, [online] Availalble at: http://www.jstor.org/stable/ 4227282 [Accessed 17 October 2015].

15. Holton, A.G. (2004), Perspectives. Defining Risks, Financial Analysis Journal, [e-journal] vol. 60, no. 6, pp. 19-25, Availalble at: <http://www. riskexpertise.com/papers/risk.pdf> [Accessed 25 October 2015].

16. Jehle, A.G. (1984), Individual Welfare and the Demand for Financial Instruments, Southern Economic Association, [e-journal] vol. 51, no. 1, pp. 116-134, DOI: 10.2307/1058326, Availalble at: <http://www.jstor.org/ stable/1058326> [Accessed 17 October 2015].

17. Jubak, J. (2010), Another Devil in the Financial Crisis, [online] Availalble at: http://articles.money central.msn.com/Investing/JubaksJournal/anotherdevil-in-the-financial-crisis.aspx?page $=3$ [Accessed 17 October 2015].

18. Keynes, J.M. (1921), Treatise on Probability, [e-book] Londra: Macmillan And Co., Availalble at: $<$ http://www.archive.org/details/treatiseonprobab00 7528mbp >, [Accessed 25 October 2015].
19. Knight, H.F. (1921), Risk, Uncertainty and Profit, [e-book] Washington: Hart, Schaffner \& Marx, Availalble at: $<$ http://books.google.com/books?id= Ntom6_pFQMcC\&printsec $=$ frontcover\&dq= frank+knight\&hl=en\&ei=2EfFT $\cos 0 \mathrm{MSyBt} 2 \mathrm{P}_{-}$foO\& $\mathrm{sa}=X \&$ oi=book_result\&ct=book-thumbnail\& resnum $=1 \&$ sqi $=2 \&$ ved $=0 C C s Q 6 w E w A A \# v=$ onepag e\&q\&f=false $>$ [Accessed 25 October 2015].

20. MacKenzie, D. (2011), The Credit Crisis as a Problem in the Sociology of Knowledge, American Journal of Sociology, [e-journal] vol. 116, no. 6, pp. 1778-1841, DOI: http://dx.doi.org/10.1086/659639, Availalble at: http://www.jstor.org/stable/ 10.1086/659639 [Accessed 17 October 2015].

21. Friedman, M. and Savage, L. (1948), The Utility Analysis of Choices Involving Risk, The Journal of Political Economy, [e-journal] vol. 56, no. 4, pp. 279-304, Availalble at: http://www.jstor.org/stable/ 1826045, [Accessed 25 October 2015].

22. Pecican, E.Ş. (2003), Econometria pentru ... economişti. Econometrie - teorie şi aplicații, Bucureşti: Editura Economică.

23. Piraeus Bank, (2016), Produse de investiții şi managementul riscului, [online] Availalble at: $<$ http://www.piraeusbank.ro/Trezorerie/Produse-deinvestitii-si-managementul-riscului/alte_prod_ invest/Descrierea-produselor.html> [Accessed 02 March 2016].

24. Popescu, M.N. (2011), Modele de determinare a cursului valutar - cazul României, [online] Availalble at: <http://www.ipe.ro/RePEc/ WorkingPapers/cs1112-1.pdf> [Accessed 25 October 2015].

25. Raftery, J. (1994), Risk Analysis in project management, New York: E \& FN SPON.

26. Ramsey (1926), „Truth and Probability”, in Ramsey, 1931, The Foundations of Mathematics and other Logical Essays, Ch. VII, p.156-198, edited by R.B. Braithwaite, London: Kegan, Paul, Trench, Trubner \& Co., New York: Harcourt, Brace and Company, Availalble at: <http://fitelson.org/ probability/ramsey.pdf>, http://cepa.newschool. edu/het/ [Accessed 25 October 2015].

27. Schoemaker, J.H.P (1982), The Expected Utility Model: Its Variants, Purposes, Evidence and Limitations, Journal of Economic Literature, [e-journal] vol. 20, no. 2, pp. 529-563, Availalble at: 
< http://www.jstor.org/stable/2724488> [Accessed 25 October 2013].

28. Skidelsky, R.J.A. (2009) Keynes: The Return of the Master, New York: Public Affairs.

29. Stiglitz, J. (2009), Interview. [online] Availalble at: $<$ http://www.pbs.org/wgbh/pages/ frontline/ warning/themes/derivatives.html> [Accessed 17 October 2015].

30. Summers, G. (2010), Why Derivatives Caused Financial Crisis, [online] Availalble at: http:// seekingalpha.com/article/198197-whyderivatives-caused-financial-crisis, [Accessed 17 October 2015]. 